AL. $2.2004-16$

\section{Fish : Widilife} Division

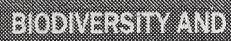
SPEOESAT Risk SEOT10N

\section{Magrath Northern Leopard Frog Reintroduction Project - Year 1 Progress Report}

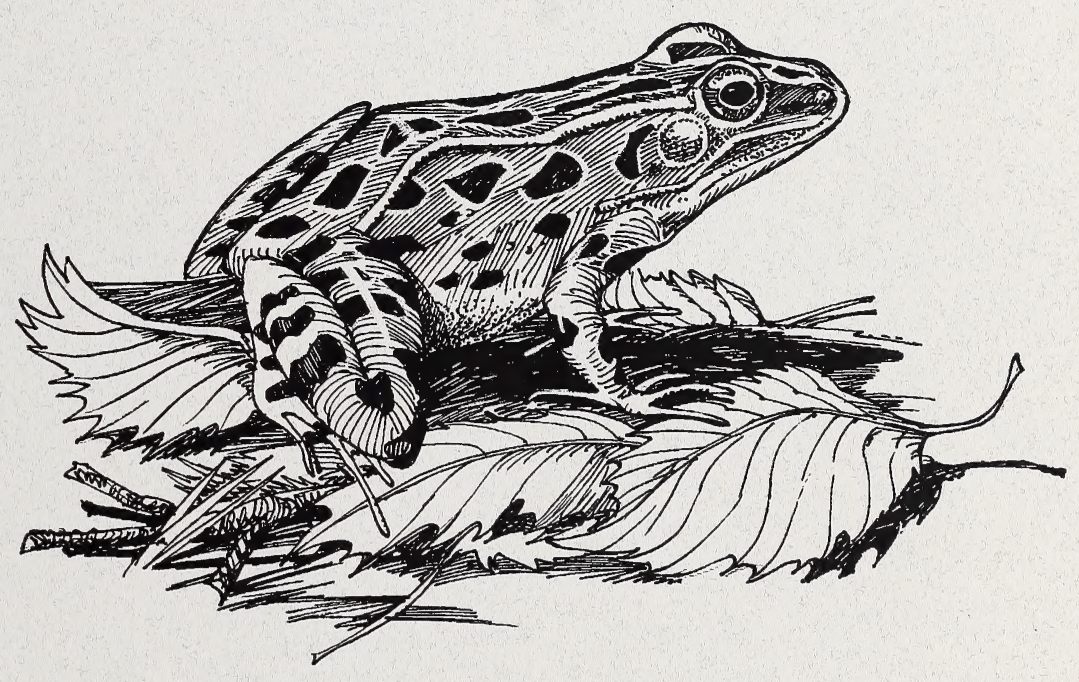


Digitized by the Internet Archive in 2016 


\section{Magrath Northern Leopard Frog Reintroduction Project - Year 1 Progress Report}

Kathryn A. Romanchuk

Alberta Species at Risk Report No. 79

November 2003

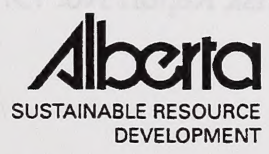

Fish \& Wildlife 
Publication No. I/135

ISBN: 0-7785-2948-7 (Printed Edition)

ISBN: 0-7785-2949-5 (On-line Edition)

ISSN: 1496-7219 (Printed Edition)

ISSN: 1496-7146 (On-line Edition)

Illustration by: Brian Huffman

For copies of this report, contact:

Information Centre- Publications

Alberta Environment/ Alberta Sustainable Resource Development Main Floor, Great West Life Building 9920- 108 Street

Edmonton, Alberta, Canada T5K 2M4

Telephone: (780) 422-2079

OR

Information Service

Alberta Environment/ Alberta Sustainable Resource Development \#100, 3115- 12 Street NE

Calgary, Alberta, Canada T2E 7J2

Telephone: (403) 297- 3362

OR

Visit our web site at:

http://www3.gov.ab.ca/srd/fw/riskspecies/

This publication may be cited as:

Romanchuk, K.A. 2003. Magrath northern leopard frog reintroduction project- year 1 progress report. Alberta Sustainable Resource Development, Fish and Wildlife Division, Alberta Species at Risk Report No. 79. Edmonton, AB. 


\section{TABLE OF CONTENTS}

ACKNOWLEDGEMENTS .................................................................................................. iii

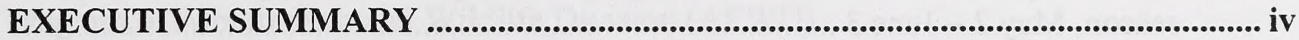

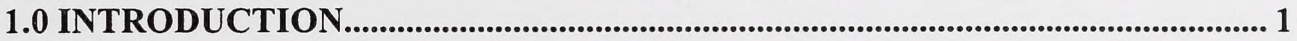

2.0 STUDY AREA........................................................................................................ 1

2.1 Egg Mass Collection Site: Michel Reservoir ........................................................... 2

2.2 Egg Mass Collection Site: Strathcona Island Park, Medicine Hat............................ 2

2.3 Egg Mass Rearing Site: Pothole Creek .................................................................... 3

2.4 Egg Mass Rearing and Release Site: Dudley's Pond.............................................. 3

3.0 METHODS ................................................................................................................ 3

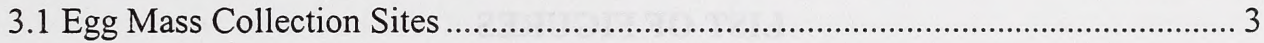

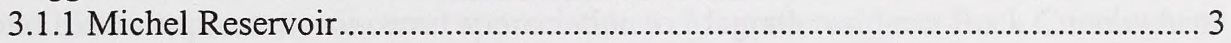

3.1.2 Strathcona Island Park, Medicine Hat ............................................................... 4

3.2 Rearing and Release Site Assessments ................................................................. 4

3.3 Egg Mass Collection, Transport, and Rearing ........................................................ 4

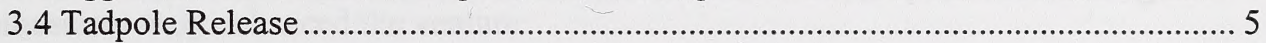

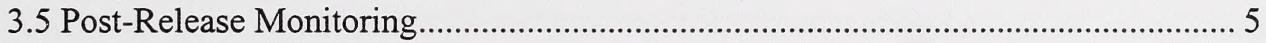

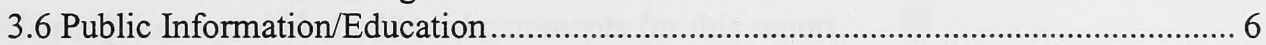

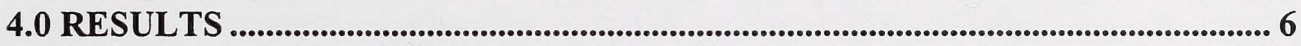

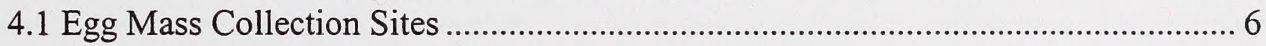

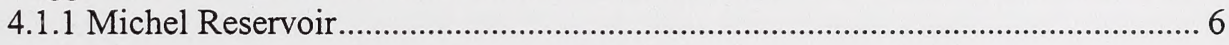

4.1.2 Strathcona Island Park, Medicine Hat ………................................................ 6

4.2 Egg Mass Collection, Transport, and Rearing ....................................................... 6

4.3 Egg Mass and Tadpole Management.................................................................... 7

4.4 Water Quality and Temperature......................................................................... 7

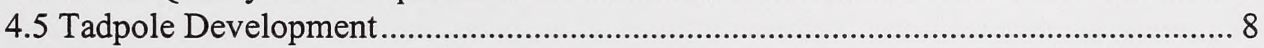

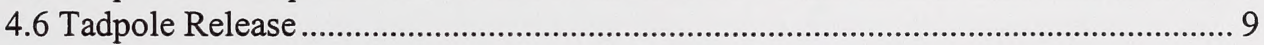

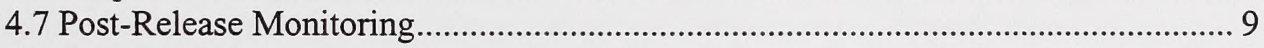

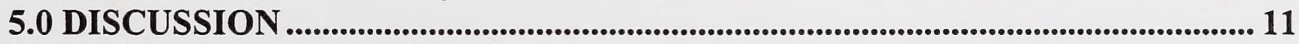

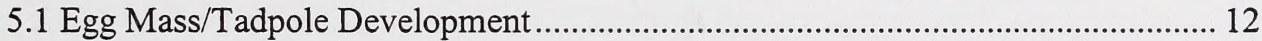

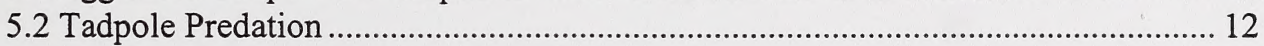

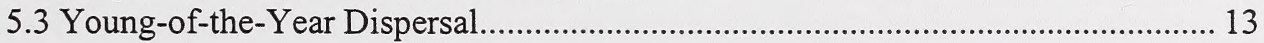

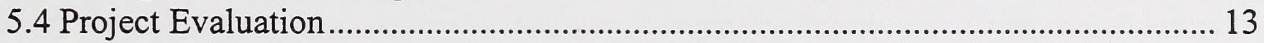

6.0 RECOMMENDATIONS/FUTURE MANAGEMENT .......................................... 13

7.0 LITERATURE CITED .............................................................................................................. 15

8.0 PERSONAL COMMUNICATIONS............................................................................. 15

APPENDIX A - Magrath Northern Leopard Frog Reintroduction-Project Area .......... 16

APPENDIX B - Photos taken during 2003 field season ............................................ 17

APPENDIX C - Numbers and locations of frogs observed throughout the 2003 field season, between July 15 and October 24 


\section{LIST OF TABLES}

Table 1. Water temperatures recorded at rearing sites during 2003 rearing season, May 2 - June 3

Table 2. Significant dates relevant to the hatching and development of the two egg masses collected in 2003 . 9

Table 3. Numbers of tadpoles counted from the two egg masses collected in 2003 9

\section{LIST OF FIGURES}

Figure 1. Map of Alberta (south of $55^{\circ}$ latitude) indicating locations of the egg mass collection site and rearing and release sites for the 2003 Magrath Northern leopard frog reintroduction project 


\section{ACKNOWLEDGEMENTS}

This project was made possible through project funding received from the Species at Risk Program of Alberta Fish and Wildlife Division (AFWD).

Special thanks to Richard Quinlan (AFWD) for initiating this project and to Brad Downey (ACA) for building the aquatic predator exclosures and his assistance at the beginning of the 2003 field season. Thank you also to Len Lupyczuk (AFWD) for providing us with information about the source pond in Medicine Hat. Finally, my acknowledgements would not be complete without extending a special thank you to Kris Kendell (ACA) for sharing his advice and expertise throughout this endeavor.

I would like to express my sincerest appreciation to Magrath residents Buck Cunningham and DeVar Dahl for their assistance and support throughout the project. The project was initiated as a result of their desire to see northern leopard frogs, once a common species in Magrath, reintroduced into native habitat. Their contribution of volunteer time and enthusiasm truly enhanced the venture.

Richard Quinlan provided editorial comments for this report. 


\section{EXECUTIVE SUMMARY}

Prior to the late 1970's, the northern leopard frog (Rana pipiens) was a common and widely distributed amphibian throughout central and southern Alberta. Unfortunately, the northern leopard frog has vanished from much of its former range in the province and due to the continued declining populations it was designated as Threatened under Alberta's Wildlife Act in 1996. Because the small number of remaining populations of leopard frogs are patchy and separated by large areas of unsuitable habitat, their re-establishment into previously occupied habitat may rely on transplanting individuals or egg masses from existing major breeding populations in southern Alberta.

A reintroduction project was initiated in Magrath in spring 2003 with the primary objective of re-establishing a breeding population of leopard frogs in its formerly occupied native habitat in the area. Two egg masses were collected from a pond in Medicine Hat that was potentially going to be destroyed later in the summer. The egg masses were transferred to the Pothole Creek area in Magrath, set inside two separate floating aquatic predator exclosures, and anchored into place at two pre-determined rearing sites. Once the egg masses hatched and the hatchlings had developed into mobile tadpoles they were released directly into suitable habitat. By June 3, 2003 a total of 5,621 tadpoles were released at various locations along a pond known locally as Dudley's Pond, which had also served as one of the rearing sites. The dispersal of frogs into the surrounding habitat was observed and documented weekly, at minimum, and approximate dispersal distances were recorded. Post-release monitoring commenced 15 July 2003 and terminated the last week of October when weather conditions became suitable for the frogs to submerge for the winter.

Preliminary success of the reintroduction project will be achieved in spring 2004 if frogs can be confirmed as having overwintered successfully. Further success of the project will be determined once breeding becomes evident and can be confirmed through the discovery of deposited egg masses. Overall success can be considered once a long-term self-sustaining population of northern leopard frogs is established in the Pothole Creek area. 


\subsection{INTRODUCTION}

The northern leopard frog (Rana pipiens) was once abundant and widespread throughout Alberta, and it was a common sight in the Magrath natural areas around Pothole Creek (Dahl, pers. comm.). The northern leopard frog was listed as a species "At Risk" in Alberta in 1991 due to vanishing populations from much of the historic range, and was legislated as Threatened under Alberta's Wildlife Act in 1996. The few remaining breeding populations of leopard frogs are separated by large distances, making them vulnerable to disturbance and limiting their capability to disperse into formerly occupied habitat.

In 1998 the Alberta Fish and Wildlife Division initiated a northern leopard frog reintroduction program, and in 1999 the first pilot reintroduction project was started at the Raven Brood Trout Station near Caroline, Alberta (Kendell 2001). The goal of that project was to re-establish leopard frogs in historically occupied habitats of the upper Red Deer and North Saskatchewan River drainage basins. The project has been ongoing and has shown positive results (Kendell 2002a).

The Magrath northern leopard frog reintroduction project was initiated following a request made by two local residents to staff of Alberta Fish and Wildlife Division (AFWD) and the Alberta Conservation Association (ACA) to see northern leopard frogs, once a common species in Magrath, reintroduced into historic native habitat in the area. Northern leopard frogs were last observed there in the late 1970's (Dahl and Cunningham, pers. comm.)

The goal of this project is to re-establish a breeding population of northern leopard frogs in formerly occupied native habitat in the Magrath area of southern Alberta. Success in this project could help to increase the leopard frogs' area of occurrence and thereby help recover the provincial population.

\subsection{STUDY AREA}

Magrath is located approximately $32 \mathrm{~km}$ south of Lethbridge, $A B$ in the mixed-grass natural subregion (Fig. 1). The Pothole Creek area, a natural area at the southwest edge of the town, was chosen as the reintroduction site for this project based upon it being historic native habitat for northern leopard frogs (Kendell 2002c). The Pothole Creek floodplain includes sedge, cattail, shrub, and willow communities as well as cottonwood groves and areas of grassland. Beyond the valley breaks, cultivation is the dominant land use. The Magrath Golf Club borders the southwest end of Pothole Creek, while the town of Magrath is just north of the project area. Pothole Creek originates on the Milk River ridge and runs north through Magrath, eventually flowing into the St. Mary's River. Michel Reservoir, south of the Cypress Hills and a pond in Strathcona Island Park in Medicine Hat were the two potential egg mass collection sites targeted for this project. 
㶦 Egg mass collection site

Magrath (Pothole Creek) rearing and release sites

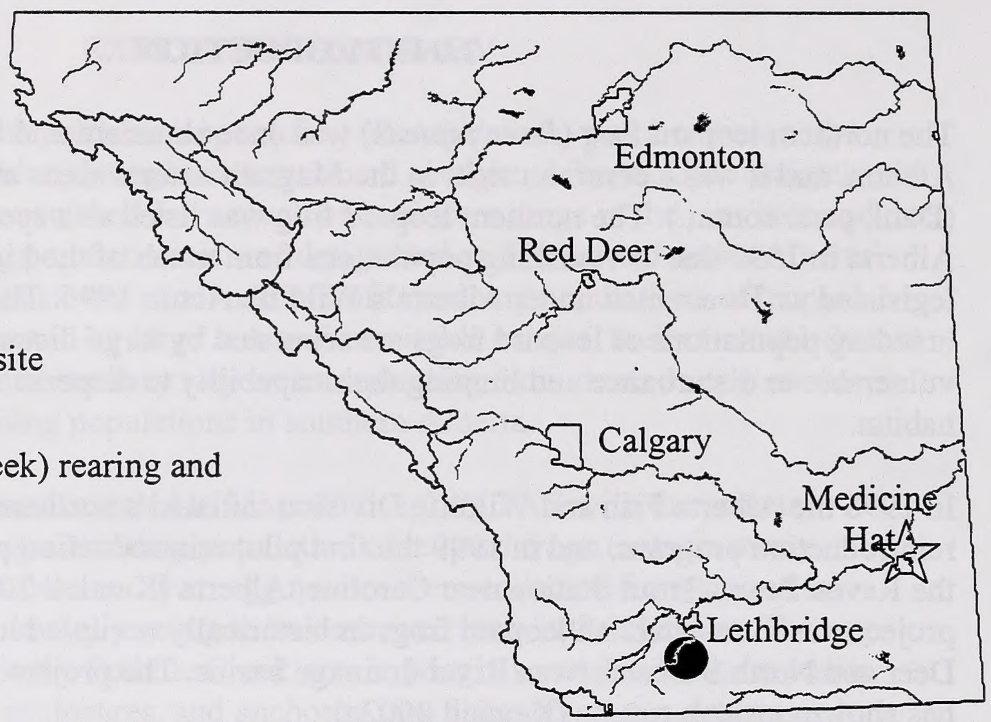

Figure 1. Map of Alberta (south of $55^{\circ}$ latitude) indicating locations of the egg mass collection site and rearing and release sites for the 2003 Magrath northern leopard frog reintroduction project

\subsection{Egg Mass Collection Site: Michel Reservoir}

Initially, Michel Reservoir (northeast of Manyberries, $A B$ ) was the primary source site considered for this project. This was based on previous records obtained from the Biodiversity / Species Observation Database (BSOD) as well as observations made during a northern leopard frog inventory in 2000/2001 (Kendell 2002c). Michel Reservoir is located $23.5 \mathrm{~km}$ southwest of Elkwater, $\mathrm{AB}$ just south of the Cypress Hills. It is a day use recreation area that is stocked annually with rainbow trout. The key potential draw site was a pond on the east side of the access road. The pond contained small amounts of aquatic vegetation and downed woody debris and sparse amounts of emergent vegetation. The shoreline was muddy with light to moderate vegetative cover. Higher up the banks, vegetation became increasingly heavier providing good cover for frogs. Native grassland surrounded the area.

\subsection{Egg Mass Collection Site: Strathcona Island Park, Medicine Hat}

The pond in Strathcona Island Park in Medicine Hat became a priority as an egg mass collection site based on it being threatened by potential pond dewatering planned for later in the summer (Lupyczuk, pers. comm.). Strathcona Island Park is situated on the South Saskatchewan River floodplain in the city of Medicine Hat, AB. The pond runs parallel to Ross Creek and is an old oxbow that was modified by the City in 1983/1984 (Mudry, pers. comm.). It is well known by local residents that leopard frogs inhabit this pond (Nicholson, pers. comm.). The pond is narrow and contains small amounts of downed woody debris and submergent vegetation, plus sparse amounts of emergent vegetation. Much of the shoreline is muddy and lightly vegetated, providing good cover and basking opportunities for the frogs. Higher up, the banks are well vegetated, primarily with 
grasses and shrubs, with some trees present higher on the slopes.

\subsection{Egg Mass Rearing Site: Pothole Creek}

This site was situated approximately $0.6 \mathrm{~km}$ upstream of Dudley's Pond within the property of the Magrath Rod and Gun Club. A rearing site was established here in an inlet approximately $0.5 \mathrm{~km}$ west of a spillgate and $10 \mathrm{~m}$ in from the main creek channel. Water depth in the inlet during the rearing period was about $0.6 \mathrm{~m}$ and there was an abundance of algae in the area. Cattails dominated the north end of the channel while the shoreline was comprised of sedges, grasses, and shrubs. In general, this area contained healthy shrub, sedge, and cattail communities. Pike inhabit the creek. This site served as a rearing site, but the tadpoles reared here were released at Dudley's Pond.

\subsection{Egg Mass Rearing and Release Site: Dudley's Pond}

Dudley's Pond is a 1 ha wetland situated on 4 ha of private property at the southwest edge of Magrath along the Pothole Creek floodplain. It is a permanent, kidney-shaped pond that has several small springs and seeps running into it. The pond offers a variety of water depths, with the deepest area measuring approximately $1.5 \mathrm{~m}$. A cattail complex dominates the shoreline along with sedges, shrubs, and mixed grasses. There is adequate aquatic vegetation to provide cover for all age classes of leopard frogs. The deep area of the pond should provide adequate overwintering habitat for leopard frogs since it does not freeze to the bottom, while the shallow water at the southern tip of the pond exhibits favourable breeding habitat components. The area immediately surrounding the pond possesses suitable summering habitat, offering a large foraging area with plenty of food items, including an abundance of invertebrates, and both cover and basking locations for the frogs. The surrounding habitat also appeared suitable for dispersal of young-of-theyear frogs, with vegetation high enough to provide cover but not too dense for them to travel through. Fish, primarily minnow species and suckers, are known to occupy the water. Pike are not normally found in the pond, but they have appeared in the past following flood events (Cunningham, pers. comm.). Dudley's Pond served as one of the rearing sites and was the release site for this project.

\subsection{METHODS}

\section{$\underline{3.1 \text { Egg Mass Collection Sites }}$}

\subsubsection{Michel Reservoir}

On 01 May 2003 at approximately 11:15 am, a potential source pond on the east side of the access road was inspected. An intensive foot search to visually locate northern leopard frog egg masses was carried out by two researchers following the guidelines outlined in the Survey Protocol for Northern Leopard Frogs (see Kendell 2002b). The pond at Michel Reservoir was revisited on 13 May, and another search for egg masses was carried out in the early afternoon. 


\subsubsection{Strathcona Island Park, Medicine Hat}

A preliminary search for northern leopard frog egg masses was carried out in the late afternoon of 01 May 2003. The perimeter of the pond was covered on foot, focusing on areas of suitable breeding habitat. The following morning a more intensive survey of the pond took place following the same protocol used at Michel Reservoir. An additional search for egg masses in the Strathcona Island Park pond took place in the afternoon of 13 May 2003.

\subsection{Rearing and Release Site Assessments}

The Pothole Creek area had been identified as suitable northern leopard frog habitat following an initial site survey in 2001. In March 2002 seven locations in the Pothole Creek area were investigated to determine their potential suitability as rearing and release sites. Water depths, winter dissolved oxygen levels, and substrate types were recorded. Water samples were collected and analyzed for a suite of water quality parameters including levels of dissolved oxygen, $\mathrm{pH}$, alkalinity, salinity, nitrites, nitrates, phosphates, and water hardness. The project was ready to be initiated in spring of 2002, but very cold temperatures resulted in poor availability of eggs in potential source ponds. Although the search for egg masses was still underway in late May/early June, the project was finally postponed to 2003 when, on June 8, 2002 Pothole Creek flooded the floodplain and part of the town of Magrath.

When the project resumed in the spring of 2003, two out of the several different locations investigated previously were selected as being the most favourable for a successful reintroduction project. Due to the flooding experience in 2002 the site selection process evaluated susceptibility to flooding, in addition to assessing suitable cover (i.e. vegetation) and an adequate food source. Water samples were collected once again from the two selected sites and tested for the same water quality parameters tested for in 2002. Water quality was also measured for a water sample taken from the draw site in Medicine Hat.

\subsection{Egg Mass Collection, Transport, and Rearing}

On 02 May 2003, egg masses were collected from the Strathcona Island Park pond in Medicine Hat. The egg masses were placed in a clean 45-litre cooler filled with water from the draw site and transported by truck to the rearing site in Magrath. Upon arrival at the first rearing site, Dudley's Pond, half of the water in the cooler from the draw site was emptied out and replaced with water from the pond. This facilitated the mixing of the collection site and rearing pond water temperatures and water chemistry, and provided the opportunity for the egg masses to acclimatize. After a minimum 25-minute acclimatization period, predator exclosures containing the egg masses were carefully transferred from the cooler into their respective rearing sites, the tops of the exclosures were secured in place, and they were then anchored into position. The GPS locations were recorded along with the water temperatures. The aquatic predator exclosures were constructed according to designs provided by Kris Kendell (see Kendell 2001) and used to contain and protect the egg masses and tadpoles during the rearing process (Appendix B/Photo 1). 
Throughout the rearing period, the development of both egg masses was monitored every 2 days. Air and water temperatures were recorded at each visit along with observations of the egg masses and any other general observations made at the rearing sites (e.g. fish, changes in water level/flow, wildlife, etc.). Once the egg masses hatched, monitoring of the tadpoles continued in the same fashion until they were released.

\subsection{Tadpole Release}

All tadpoles were counted prior to being released (Appendix B/Photo 4). The predator exclosure containing the tadpoles was set inside a round dishwashing pan filled with water from the rearing site and brought onto level ground for ease of handling. The top of the exclosure was carefully removed and any tadpoles stuck on the sides or in the folds of the "no-see-um" mesh were washed down into the exclosure using pond water poured from a bottle. A bucket partially filled with pond water was placed next to the dishpan. Using a small plastic strainer, the tadpoles were scooped, counted, and transferred to the bucket of water (Appendix B/Photo 5). The strainer was kept under water as much as possible during the counting process to minimize the impact on the tadpoles and protect them from sun exposure. One person counted the tadpoles and called out numbers, while a second person recorded. Once several hundred tadpoles had been transferred into the bucket, they were taken to several pre-determined locations along Dudley's Pond and released directly into suitable habitat. Water in the dishpan was replaced with fresh pond water approximately halfway through the counting process. This process was repeated until all tadpoles were counted. A GPS location was recorded for each release site. The entire process took an average of 3 hours.

\subsection{Post-Release Monitoring}

Post-release monitoring of leopard frogs commenced on 15 July 2003. Dudley's Pond was the focal point for finding the first young-of-the-year frogs, so both a canoe and a foot search were used on the first day of monitoring in order to get the most complete coverage of the area. The canoe was used on one other occasion (31 July) to investigate Dudley's Pond, since some areas were too difficult to access on foot or were too deep. While initial surveys focused on the shoreline of Dudley's Pond, as the frogs dispersed the area to search expanded from the pond. Later in the season the Pothole Creek area became the primary focus for leopard frog surveys in order to document dispersal distances (Appendix A).

Surveys generally started at 11:30 am and were completed by 4:00 pm. Walking transects were established around Dudley's Pond, upstream from Dudley's Pond along both sides of Pothole Creek to the spillgate and downstream to the Highway 62 bridge crossing, along the southwest edge of the creek west of the spillgate up to the golf course, along the east side of the Galt Canal, along the Pothole Creek rearing site (inlet), and a short transect along the northwest edge of the creek from west of the spillgate to the tip of the inlet.

Walking transects were conducted within the study area every 2-3 days from late July into early September to monitor the dispersal of the frogs. From mid-September surveys 
were carried out approximately once a week until the last week of October when weather conditions became suitable for winter submergence.

\subsection{Public Information/Education}

Prior to and during the project, local news releases were issued. Residents were also informed of the project through occasional personal contact with the researcher during the field season. Ongoing communication and involvement was maintained with the two Magrath residents who requested the initiation of this project.

\subsection{RESULTS}

\subsection{Egg Mass Collection Sites}

\subsubsection{Michel Reservoir}

The search of the potential source pond on 01 May 2003 resulted in only one small egg mass being found in a small sheltered arm running north from the main pond, approximately $1.5 \mathrm{~m}$ from the east shore attached to aquatic vegetation. A total of 5 northern leopard frogs and 2 boreal chorus frogs (Pseudacris maculata) were recorded at the site.

There were no additional egg masses located when the pond was revisited on 13 May, and the small egg mass that was detected on the first visit was no longer present. A substantial increase in water level was noted. Only 2 leopard frogs were observed on this date. Chorus frogs were actively calling and one western painted turtle (Chrysemys picta) was observed in the pond. The turtle sighting was subsequently submitted to the BSOD database.

\subsubsection{Strathcona Island Park, Medicine Hat}

The preliminary search for leopard frog egg masses on 01 May 2003 resulted in finding two large egg masses; there were no additional egg masses detected in the pond the following day. The supplementary search for egg masses on 13 May was unsuccessful. Eleven leopard frogs were observed on that date.

\subsection{Egg Mass Collection, Transport, and Rearing}

On 02 May 2003 at 11:45 am two large leopard frog egg masses were collected from the pond in Strathcona Island Park in Medicine Hat. The egg masses were within close proximity of each other, located approximately $2.5 \mathrm{~m}$ from the shore close to the water's surface attached to a branch of submerged downed woody debris. Since there were no additional egg masses located at the other potential draw site at Michel Reservoir, the Strathcona Island Park pond served as the only collection site for this project.

The first egg mass collected was very compact and firmly attached to a branch of submerged downed woody debris. The branch and attached egg mass were cut off from the rest of the tree and carefully transferred to a clean water-filled pail and then into the cooler. A small piece of styrofoam was attached to the top end of the branch to keep the 
egg mass suspended and prevent it from banging against the bottom of the cooler during transport. The second egg mass collected was also attached to a branch of a submerged broken tree limb, however, it exhibited the first signs of hatching and therefore was much less condensed. Consequently, an aquatic predator exclosure was placed in the top of the cooler and the egg mass was then set inside it. This kept it contained and separate from the other egg mass during transportation.

The cooler containing both egg masses arrived at the Magrath rearing pond at approximately 2:30 pm on 02 May. The egg mass being reared at Dudley's Pond was anchored into position along the edge of open water and emergent cattails at $3: 15 \mathrm{pm}$. Water depth at the rearing site was $0.75 \mathrm{~m}$ (Appendix B/Photo 2).

The second egg mass was transported in another predator exclosure inside the cooler to the Pothole Creek rearing site. The egg mass was anchored into position at 5:00 pm. Water depth in the channel was approximately $0.60 \mathrm{~m}$ (Appendix B/Photo 3).

\subsection{Egg Mass and Tadpole Management}

The aquatic predator exclosures proved effective in safeguarding the egg masses and developing tadpoles from aquatic, avian, and potential terrestrial predators. Their design also allowed the egg masses to be submerged just below the water surface, which protected them somewhat from the elements and kept the eggs suspended in the warmest part of the water, which promotes egg development. The exclosures were also very useful when one of them was used inside a cooler to contain an egg mass during transportation from the collection site to the rearing site.

\subsection{Water Quality and Temperature}

Water quality tests conducted on samples collected from the draw site and two rearing sites included levels of dissolved oxygen, $\mathrm{pH}$, alkalinity, salinity, nitrites, nitrates, phosphates, water hardness, and water temperature. Results of the water quality tests showed little difference between the three sites and did not reveal any concerns. On the day the egg masses were collected and transferred, there was only a slight difference in water temperatures between the draw site $\left(12^{\circ} \mathrm{C}\right)$ and two rearing sites $\left(13^{\circ} \mathrm{C}\right.$ at the Pothole Creek site and $14^{\circ} \mathrm{C}$ at Dudley's Pond).

Water temperatures fluctuated significantly during the first week of the rearing period. At Dudley's Pond the temperature dropped from $14^{\circ} \mathrm{C}$ on 02 May to $7^{\circ} \mathrm{C}$ on $06 \mathrm{May}$, and by 11 May it rose back up to $15.5^{\circ} \mathrm{C}$. The water temperature changed even more drastically at the Pothole Creek site, dropping from $13^{\circ} \mathrm{C}$ on 02 May to $4.2^{\circ} \mathrm{C}$ on 06 May and then rising up to $15.5^{\circ} \mathrm{C}$ on 11 May. After 11 May, water temperatures at both rearing sites remained above $14^{\circ} \mathrm{C}$. The water temperature of the rearing site at Dudley's Pond was consistently warmer than the Pothole Creek site (Table 1). 
Table 1. Water temperatures recorded at rearing sites during 2003 rearing season, May 2 - June 3

\begin{tabular}{|c|c|c|}
\hline \multirow{2}{*}{ Date } & \multicolumn{2}{|c|}{ Water Temperature $\left({ }^{\circ} \mathrm{C}\right)$} \\
\cline { 2 - 3 } & Dudley's Pond & Pothole Creek \\
\hline 2-May & 14 & 13 \\
\hline 6-May & 7 & 4.2 \\
\hline 8-May & 8 & 4.2 \\
\hline 11-May & 15.5 & 15.5 \\
\hline 14-May & 17 & 17 \\
\hline 15-May & $\mathrm{N} / \mathrm{a}$ & 17 \\
\hline 16-May & 15 & $\mathrm{~N} / \mathrm{a}$ \\
\hline 19-May & 15 & 14 \\
\hline 21-May & 17 & 15 \\
\hline 23-May & 20 & 17 \\
\hline 24-May* & 23 & $\mathrm{~N} / \mathrm{a}$ \\
\hline 26-May & $\mathrm{N} / \mathrm{a}$ & 19 \\
\hline 28-May & $\mathrm{N} / \mathrm{a}$ & 19.8 \\
\hline 3-Jun* & 16 & 15 \\
\hline
\end{tabular}

N/a: water temperature not taken

*24-May: tadpoles reared at Dudley's Pond released

*3-Jun: tadpoles reared at Pothole Creek released

\subsection{Tadpole Development}

Significant dates relevant to the hatching and development process were recorded for the two egg masses collected (Table 2). A notable difference in hatching times was observed. The egg mass in Dudley's Pond had shown the first signs of hatching when it was collected on 02 May 2003. By 08 May the egg mass had almost completely hatched, and by 11 May hatching was complete. The hatchlings were confined to the predator exclosure for an additional 12 days so they could continue feeding and develop into larger, more mobile tadpoles prior to being released.

The egg mass at the Pothole Creek site did not begin hatching until 19 May. This was seventeen days after being transferred from Medicine Hat to the rearing site in Magrath. Although it took a considerable amount of time before the egg mass began to hatch, the hatching process was complete within one week. The hatchlings were confined to the predator exclosure for an additional 7 days after complete hatch to continue feeding and develop into larger tadpoles prior to their release. By 03 June the tadpoles had developed substantially, were swimming freely, and were released. 
Table 2. Significant dates relevant to the hatching and development of the two egg masses collected in 2003

\begin{tabular}{|l|l|l|l|l|}
\hline Rearing Site & $\begin{array}{l}\text { Egg Mass } \\
\text { Collection } \\
\text { Date }\end{array}$ & $\begin{array}{l}\text { Hatching - } \\
\text { Initiation }\end{array}$ & $\begin{array}{l}\text { Hatching - } \\
\text { Complete }\end{array}$ & $\begin{array}{l}\text { Tadpoles } \\
\text { Released }\end{array}$ \\
\hline Dudley's Pond & 02 May 2003 & 02 May 2003 & 11 May 2003 & 24 May 2003 \\
\hline Pothole Creek & 02 May 2003 & 19 May 2003 & 26 May 2003 & 03 June 2003 \\
\hline
\end{tabular}

\subsection{Tadpole Release}

The first release took place on 24 May 2003. Weather conditions were sunny and hot with a light breeze. Air temperature was $25^{\circ} \mathrm{C}$ at the start, rising to $30^{\circ} \mathrm{C}$, and the water temperature in Dudley's Pond was $23^{\circ} \mathrm{C}$ at noon, reaching $25^{\circ} \mathrm{C}$ by late afternoon. A total of 3,103 tadpoles were counted from the egg mass that developed in Dudley's Pond (Table 3). One hundred sixty-six of those tadpoles were dead, resulting in 2,937 tadpoles being released.

The second release took place on 03 June 2003. Weather conditions were sunny and warm with a very light breeze; air temperature was $17^{\circ} \mathrm{C}$. A total of 2,732 tadpoles were counted, with 48 dead, resulting in 2,684 tadpoles being released. Due to concerns about the slower development of the second egg mass at the Pothole Creek site, observations of northern pike, and the efficiency of monitoring dispersal from one rather than two release sites, a decision was made to release the Pothole Creek tadpoles into Dudley's Pond. This resulted in a total of 5,621 tadpoles being released at various locations along the east side of Dudley's Pond.

Table 3. Numbers of tadpoles counted from the two egg masses collected in 2003

\begin{tabular}{|l|l|l|l|l|l|}
\hline Egg Mass & $\begin{array}{l}\text { Release } \\
\text { Date }\end{array}$ & $\begin{array}{l}\text { Living } \\
\text { Tadpoles } \\
\text { Counted }\end{array}$ & $\begin{array}{l}\text { Dead } \\
\text { Tadpoles } \\
\text { Counted }\end{array}$ & $\begin{array}{l}\text { Total } \\
\text { Tadpoles } \\
\text { Counted }\end{array}$ & $\begin{array}{l}\text { Tadpole } \\
\text { Survival Rate } \\
(\%) \text { to Release }\end{array}$ \\
\hline $\begin{array}{l}\text { \#1 (Dudley's } \\
\text { Pond) }\end{array}$ & $\begin{array}{l}\text { 24 May } \\
\text { 2003 }\end{array}$ & 2,937 & 166 & 3,103 & 94.7 \\
\hline $\begin{array}{l}\text { \#2 (Pothole } \\
\text { Creek) }\end{array}$ & $\begin{array}{l}\text { 03 Jun } \\
\text { 2003 }\end{array}$ & 2,684 & 48 & 2,732 & 98.2 \\
\hline TOTAL & & $\mathbf{5 , 6 2 1}$ & $\mathbf{2 1 4}$ & $\mathbf{5 , 8 3 5}$ & \\
\hline
\end{tabular}

\subsection{Post-Release Monitoring}

The first young-of-the-year frogs were observed in Dudley's Pond on 15 July 2003. This observation was of six small frogs sighted along the west side of the pond, almost directly across from their rearing site. None of the frogs were completely out of the water and they all had tails as long as their bodies. No frogs were observed on that date on the east side of the pond where the tadpoles had initially been released, although a couple of distinct "plopping" sounds were heard. 
The next inspection was one week later, on 22 July. Twenty-four frogs were observed at that time. All frogs were observed along the east side of the pond and in the very shallow water at the far south end of the pond. Most frogs were smaller than those seen a week earlier, and their tails, if present, were barely noticeable. Four frogs were on land just along the shoreline and hopped into the water as they were passed by.

The greatest number of frogs counted was on 28 July 2003, when 197 frogs were observed in and immediately surrounding Dudley's Pond. The size and development of the frogs varied greatly; some still had tails of varying lengths, while others appeared to be fully metamorphosed. Several frogs were completely in the water, some were partially in the water, and others were on land among the shoreline vegetation or in mud depressions very close to the water's edge.

On 29 July 2003 a Magrath resident reported finding a lone frog on his lawn under the sprinkler. The distance travelled would have been at least $500 \mathrm{~m}$ due north from the closest point of Dudley's Pond. The frog was returned to Pothole Creek by Alberta Fish and Wildlife staff and released into suitable habitat. On the same day, two Magrath residents reported seeing 3 leopard frogs approximately $320 \mathrm{~m}$ downstream of Dudley's Pond on the banks of Pothole Creek ( 2 on one side, 1 on the other) about 10m south of the footbridge located below the camp kitchen furthest from the fish pond. All three frogs jumped into the creek as they were approached. These frogs would have travelled downstream to reach this point or perhaps used the extensive cattail complex situated east of the northern tip of Dudley's Pond as an aquatic corridor to the edge of the creek.

The second highest number of frogs counted in the immediate pond area was on 31 July. This observation was made while canoeing around the pond. A total of 108 frogs were detected. Their distribution was similar to that recorded three days prior, with frogs along both sides of the pond and in the shallow water at the southern tip of the pond. The majority of frogs were in the water, although a few were noted along the shoreline very close to the water's edge.

By the first week of August it became apparent that an increasing number of frogs had begun to disperse from the release site. On 07 Aug 2003 an intensive search of the habitat adjacent to Dudley's Pond both upstream and downstream along Pothole Creek was carried out with the assistance of two Magrath residents. The survey covered approximately $1.2 \mathrm{~km}$ of ground from the closest point of Dudley's Pond to Pothole Creek, extending upstream approximately $540 \mathrm{~m}$ to the spillgate and downstream $640 \mathrm{~m}$. The search resulted in locating 25 frogs, the majority of which were found approximately $145 \mathrm{~m}$ upstream on the east side of Pothole Creek in an open area comprised of a cattail/sedge community near an old beaver pond. A search for frogs along the east side of Dudley's Pond was also completed that afternoon that resulted in 81 frogs of various sizes being observed. By 14 Aug several frogs had dispersed approximately $500 \mathrm{~m}$ upstream to within $40 \mathrm{~m}$ of the spillgate.

On 26 Aug 2003 the first leopard frogs were observed along the east side of the old Galt Canal approximately $465 \mathrm{~m}$ northeast (downstream) of the release site. Three frogs were 
spotted among the sedges and mixed grasses within an open cattail complex along the shoreline (Appendix B/Photo 6). During a survey of the canal on 05 Sept following the same route, a total of five frogs were seen. Three of them were recorded at locations further upstream than the previous visit. The frogs observed along the canal throughout the study were consistently found along the shoreline in habitat comprised of cattails with a mixture of sedges, rushes, native and non-native grasses, and willows.

The furthest upstream dispersal distance of $1.2 \mathrm{~km}$ was recorded on 02 Oct 2003. The frogs observed were along the shoreline of Pothole Creek among cattails, sedges, and grasses. At this point, they were just downstream of the Magrath Golf Club. The furthest downstream dispersal distance recorded during the field season was $400 \mathrm{~m}$ (northeast of the release site), noted on 07 Aug 2003. The frogs were found in and around a small, shallow ephemeral wetland along the Pothole Creek floodplain.

Frogs were last observed above water on 24 October. Five of them were spotted east of the spillgate in two locations along the west side of Pothole Creek. Both locations were directly across from Dudley's Pond, approximately $40 \mathrm{~m}$ apart from each other. The water temperature in Pothole Creek on 24 October was $7^{\circ} \mathrm{C}$ and $10.5^{\circ} \mathrm{C}$ in Dudley's Pond. The total numbers of frogs observed throughout the 2003 field season are available in Appendix C.

\subsection{DISCUSSION}

This project was carried out in a natural environment under less controlled conditions than the previous reintroduction project at the Raven Brood Trout Station near Caroline, $A B$ (see Kendell 2001). Because the release site was so large it was not feasible to carry out any type of intensive post-release monitoring, such as a total census of young-of-theyear frogs emerging from the pond.

The number of frogs observed throughout the study period is probably not representative of the actual number of frogs occurring within the Magrath reintroduction area. As the frogs dispersed away from the release site and into the surrounding habitat, the area to search became increasingly larger, increasing the likelihood that frogs would not be detected. Additionally, the reintroduction area contained vast amounts of extensive cattail complexes, many of which were impassable, hindering the searches. The greatest numbers of frogs were observed when they were still in a fairly concentrated area at the release site and when the researcher had volunteers assisting with the foot searches.

The walking transects that were established within the project area may also have influenced the number of frogs that were observed on any given survey date. Some walking transects were longer than others, some contained larger areas of suitable leopard frog habitat, and some transects contained areas that were more easily accessible than others. 


\subsection{Egg Mass/Tadpole Development}

Egg mass hatching times and tadpole development rates vary and they are also water temperature dependent (Russell and Bauer 1993, cited in Wagner 1997). Previous studies have shown that under cooler temperatures, hatching times are extended and tadpole development rates are reduced (Kendell 2001). The difference in hatching times and tadpole development rates noted between the two egg masses collected in 2003 also supported this correlation.

Although the egg mass reared at the Pothole Creek site took longer to hatch initially (17 days), the tadpoles developed at a faster rate than the tadpoles reared in Dudley's Pond. The tadpoles reared in Pothole Creek were confined to the exclosure for an additional 7 days after complete hatch before they were ready to be released, versus 12 days for the tadpoles from Dudley's Pond. From the time the egg mass at the Pothole Creek site showed the first signs of hatching (19 May), the water temperature remained warm, ranging between $14^{\circ} \mathrm{C}$ and $19.9^{\circ} \mathrm{C}$. On the other hand, the egg mass placed in Dudley's Pond on 02 May had already started to hatch, therefore, both the hatchlings and the remaining portion of the egg mass were subjected to the fluctuating water temperatures at the start of the rearing period that dropped from $14^{\circ} \mathrm{C}$ down to $7^{\circ} \mathrm{C}$ within a 48 -hour period and then rose back up to $15.5^{\circ} \mathrm{C}$ after another 72 hours. This exposure to the sudden and dramatic changes in water temperature may have accounted for the slower tadpole development rate compared to the other egg mass.

Despite both egg masses enduring some less than optimal environmental conditions at the beginning of the rearing period, hatching success was high for the two egg masses, with tadpole survival rates of $94.7 \%$ and $98.2 \%$, respectively. The egg mass reared in Dudley's Pond experienced higher mortality, which may be attributed to possible negative effects associated with transporting the egg mass while it was hatching and/or as a result of the extreme fluctuations in water temperature during the early stages of development.

Based on field observations during the rearing period, the availability of food did not appear to be a limiting factor for the tadpoles during the growth and development stages. Aquatic vegetation and algae was abundant at both rearing sites, in addition to a wide variety of invertebrates.

\subsection{Tadpole Predation}

Throughout the field season, there was no predation observed on tadpoles or young-ofthe-year frogs. Fish did not appear to be a major threat in Dudley's Pond as it is likely there were only minnow and sucker species present, although pike are present in Pothole Creek. Pelicans were noted at the release site on a couple of occasions, however it was during the time when the tadpoles were very small so it is unlikely they would have been targeted. More likely, the tadpoles would have been taken inadvertently when the pelicans were feeding on fish. Several garter snakes (Thamnophis spp.) were observed around Dudley's Pond throughout the study period. 


\subsection{Young-of-the-Year Dispersal}

Since the frogs were not fitted with any type of tracking device it was impossible to record exact travel distances. Furthermore, it was also impossible to know what route the frogs took upon dispersing. As a result, an assumption was made that the frogs took the easiest route possible. Therefore, the dispersal distances were approximated using the closest point of the release site (Dudley's Pond) to Pothole Creek and then the direct distance from that point on Pothole Creek to the observation points. This assumed the frogs would make their way to the creek to facilitate their dispersal. Seburn et al. (1993) found that young-of-the-year leopard frogs used streams for dispersal, and suggested that dispersal routes and the distances young frogs successfully disperse are influenced by the presence of aquatic corridors. The field observations of young-of-the-year frogs along the Galt Canal and Pothole Creek seem to support this.

\subsection{Project Evaluation}

Some of the preliminary successes of this project include finding egg masses at the selected source site in Medicine Hat, transferring them to and rearing them successfully at the reintroduction site in Magrath, and finally observing the young frogs' dispersal into surrounding habitat. Additional success of the reintroduction project will be achieved in spring 2004 if frogs are detected and confirmed to have overwintered successfully. Further success of the project will be determined once breeding becomes evident and can be confirmed through the discovery of deposited egg masses. Overall success can be considered once a self-sustaining population of northern leopard frogs has been documented for several years in the Pothole Creek area.

There is a high level of local support for this project. Public awareness was heightened through a presentation to local Scout troops in late June and via a newspaper article in Magrath's local newsletter in July. Additionally, from personal encounters with Magrath residents throughout the summer and fall, their continued support of the project was very apparent.

\subsection{RECOMMENDATIONS/FUTURE MANAGEMENT}

In order to complete this project some further steps are necessary:

1. Spring 2004 monitoring of the Magrath reintroduction area to determine overwinter survival.

2. Call surveys in spring 2004 to detect any possible early breeding activity.

3. Egg searches in spring 2004 and 2005 to determine any breeding success.

4. Surveys for sub-adult and adult frogs in summer 2004.

5. An additional leopard frog egg mass transplant in spring 2004. A minimum of two more egg masses should be considered to help increase the population size and compensate for expectant high mortality rates among tadpoles and young-of-the- 
year frogs.

6. Egg mass collection sites other than the Strathcona Island Park pond should be considered for egg mass transplants in 2004 to increase genetic diversity at the Pothole Creek reintroduction area.

7. Visit Pothole Creek and Dudley's Pond at least once during the winter, preferably after freeze up, and get dissolved oxygen levels, water temperatures, and ice thickness (if relevant) to assess overwintering habitat suitability.

8. If there is overwinter survival, weigh (grams) and measure (snout-vent length) a sub-sample of frogs in spring 2004 to determine approximate health/stage of sexual maturity by measures of comparison. A Pesola could be used to weigh the frogs.

9. Modify the design of the aquatic predator exclosure by adding a zipper to the top to facilitate easier monitoring of egg masses/tadpoles during the development and growth stages.

10. Investigate other potential release sites in southern Alberta, such as areas within the Milk River drainage, which is historic native habitat for northern leopard frogs.

11. Ongoing public awareness/education: presentations to interest groups, schools, and at conferences and workshops; through the media via newspaper/newsletter articles and television; brochures and posters, etc. 


\subsection{LITERATURE CITED}

Kendell, K. 2001. Northern leopard frog reintroduction: Raven River-year 2 (2000).

Alberta Sustainable Resource Development, Fish and Wildlife Division, Alberta Species at Risk Report No.13, Edmonton, AB. 43 pp.

Kendell, K. 2002a. Northern leopard frog reintroduction: year 3 (2001). Alberta Sustainable Resource Development, Fish and Wildlife Division, Alberta Species at Risk Report No. 42, Edmonton, AB. 45 pp.

Kendell, K. 2002b. Survey protocol for the northern leopard frog. Alberta Sustainable Resource Development, Fish and Wildlife Division, Alberta Species at Risk Report No. 43, Edmonton, AB. 30 pp.

Kendell, K. 2002c. Alberta inventory for the northern leopard frog (2000/2001). Alberta Sustainable Resource Development, Fish and Wildlife Division, Alberta Species at Risk Report No.44, Edmonton, AB. 29 pp.

Russell, A.P. and A.M. Bauer. 1997. The amphibians and reptiles of Alberta. Univ. Calgary Press and Univ. Alberta Press, Calgary and Edmonton, AB. 264 pp.

Seburn, C.N.L., D.C. Seburn, and C. Paszkowski. 1993. Northern leopard frog (Rana pipiens) dispersal in relation to habitat. Unpublished report. Departments of Zoology and Geography, University of Alberta, Edmonton, AB.

Wagner, G. 1997. Status of the northern leopard frog (Rana pipiens) in Alberta. Alberta Environmental Protection, Wildlife Management Division, Wildlife Status Report No.9, Edmonton, AB. 46pp.

\subsection{PERSONAL COMMUNICATIONS}

Cunningham, Buck. Fish and Wildlife Biologist (retired). Magrath, AB.

Dahl, DeVar. Teacher and Town Councillor. Magrath, AB.

Kendell, Kris. Biologist. Alberta Conservation Association, Edmonton, AB.

Lupyczuk, Len. Conservation Officer. Alberta Sustainable Resource Development, Fish and Wildlife Division, Medicine Hat, $\mathrm{AB}$.

Mudry, Maureen. City of Medicine Hat, Parks and Outdoor Recreation Division, Medicine Hat, AB.

Nicholson, Joel. Non-Game Biologist. Alberta Sustainable Resource Development, Fish and Wildlife Division, Medicine Hat, AB. 


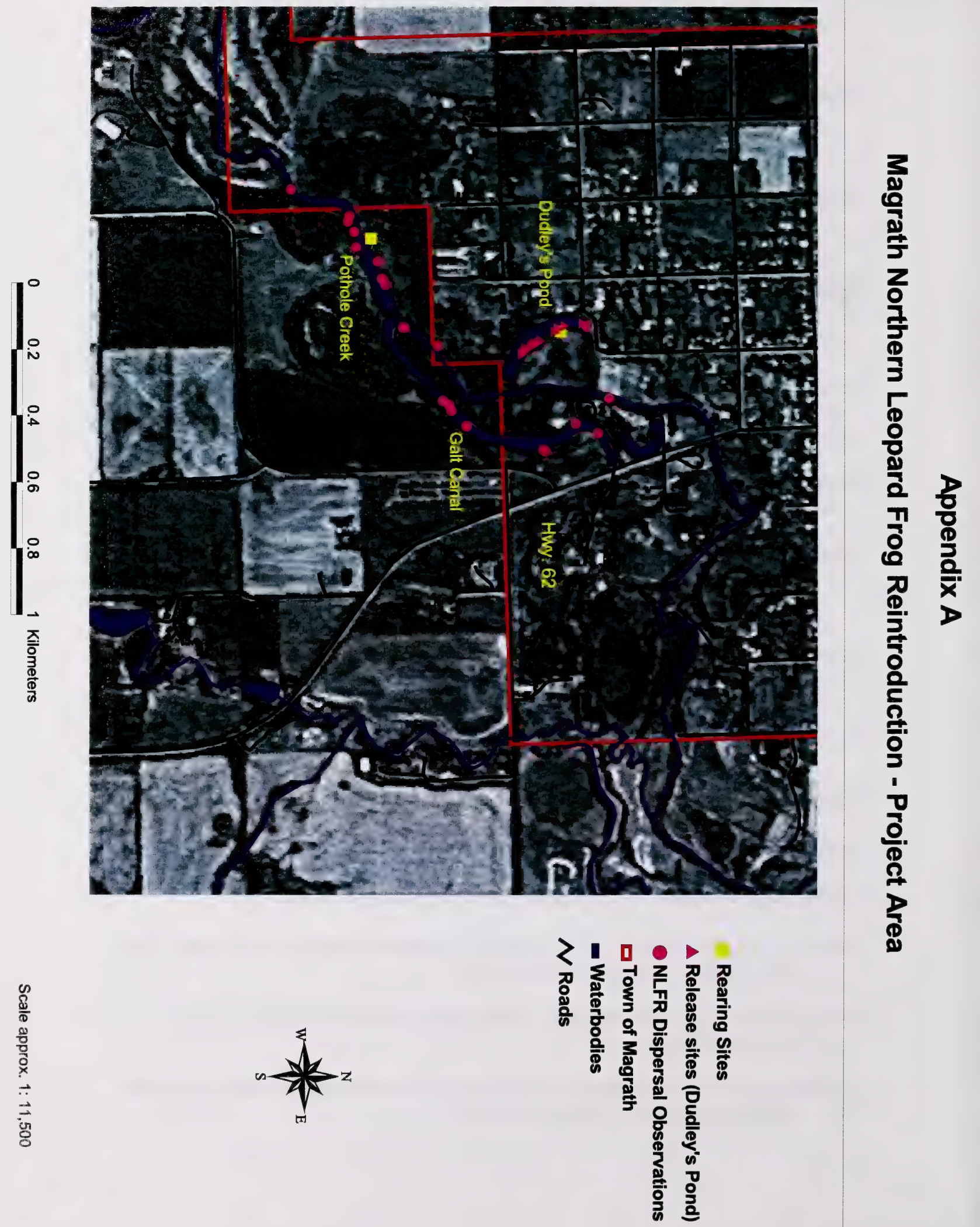




\section{APPENDIX B - Photos taken during 2003 field season}

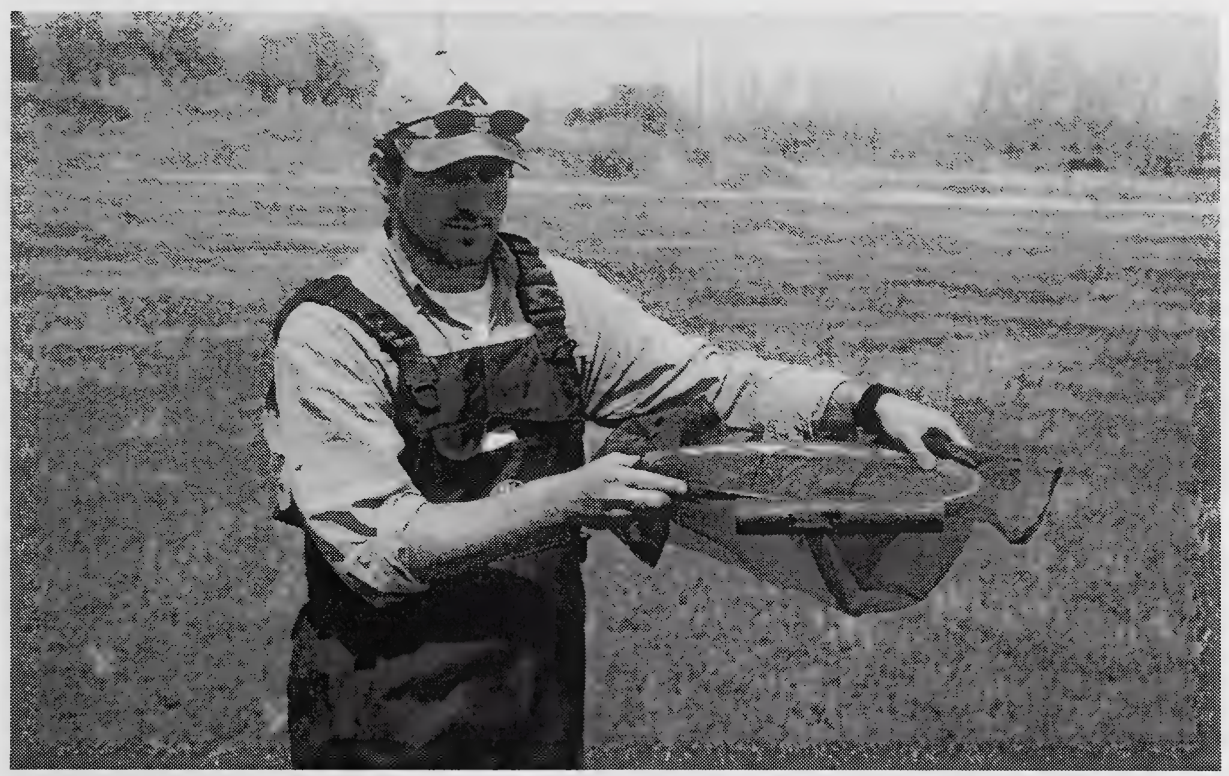

Photo 1. Aquatic predator exclosure held by B.Downey

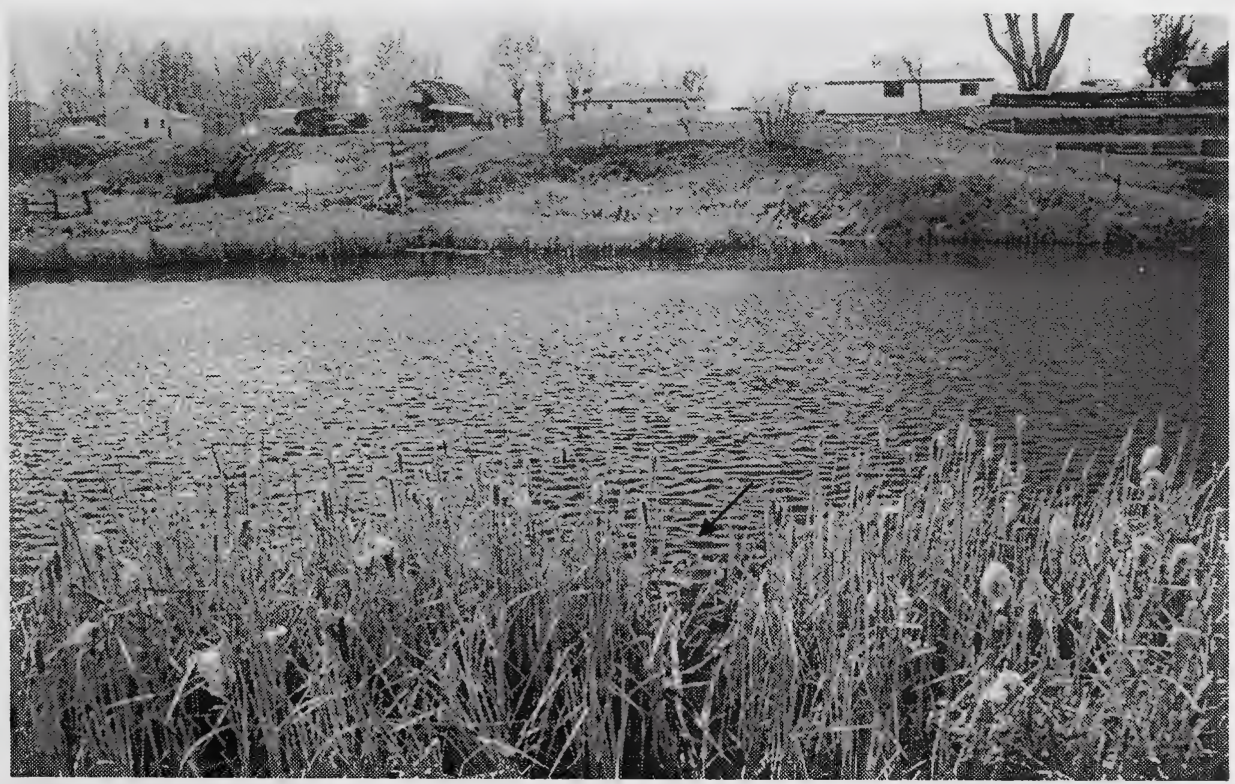

Photo 2. Predator exclosure containing egg mass anchored at the Dudley's Pond rearing site 


\section{APPENDIX B - continued}

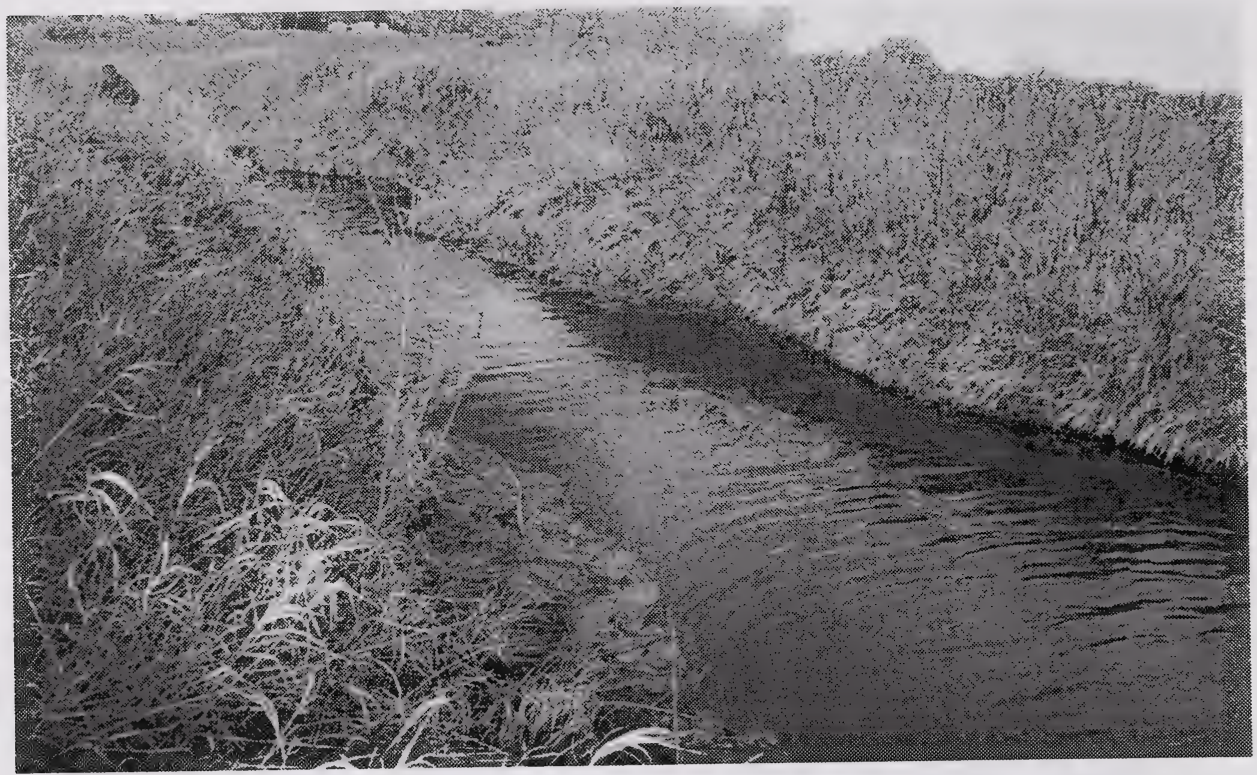

Photo 3. Pothole Creek rearing site - the predator exclosure containing the egg mass was anchored in the top left hand corner of the photo

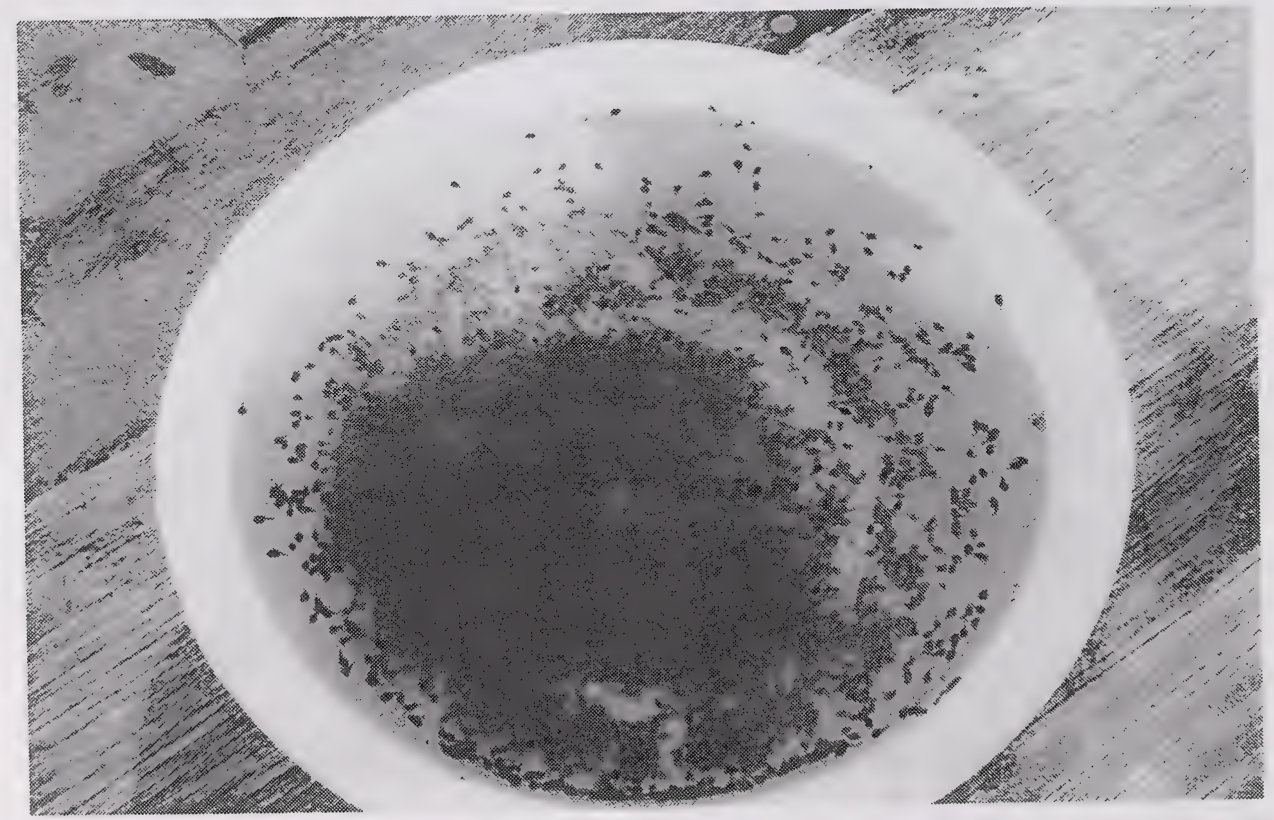

Photo 4. Tadpoles prior to release, June 3/03 
APPENDIX B - continued

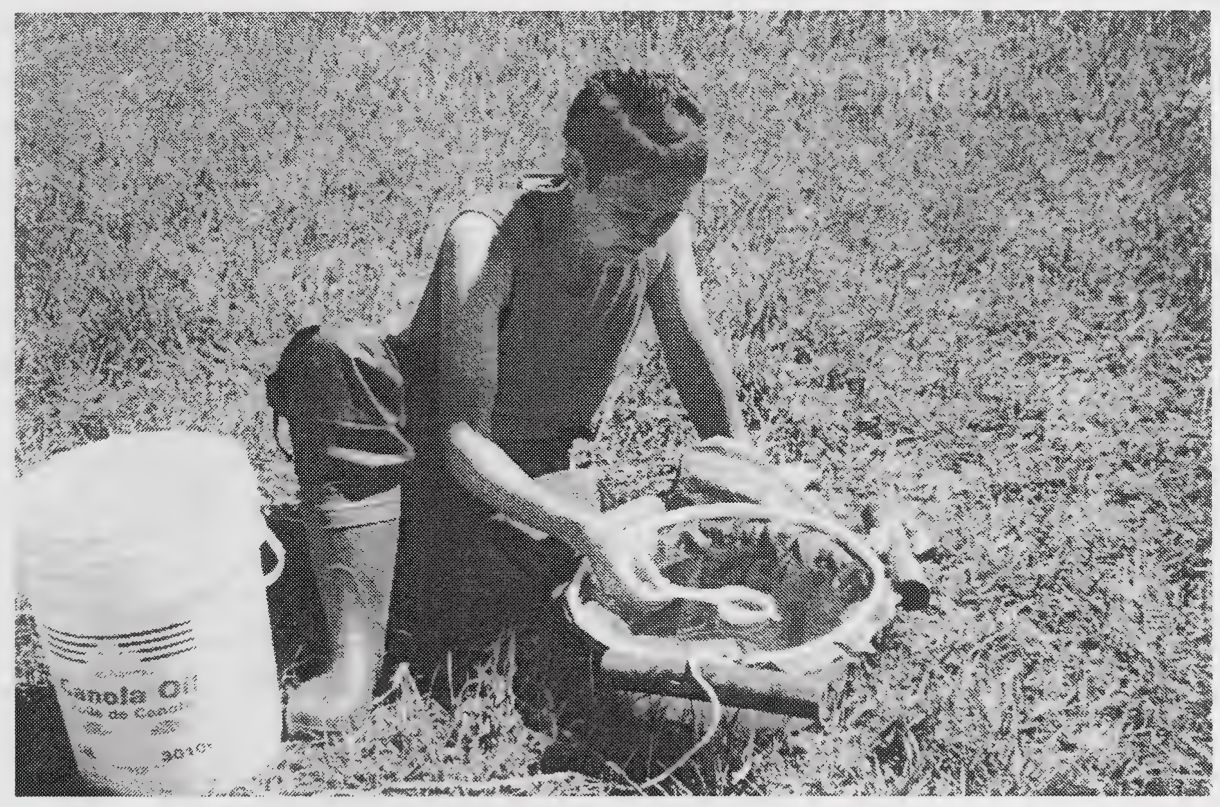

Photo 5. K. Romanchuk counting tadpoles prior to their release, May 24/03

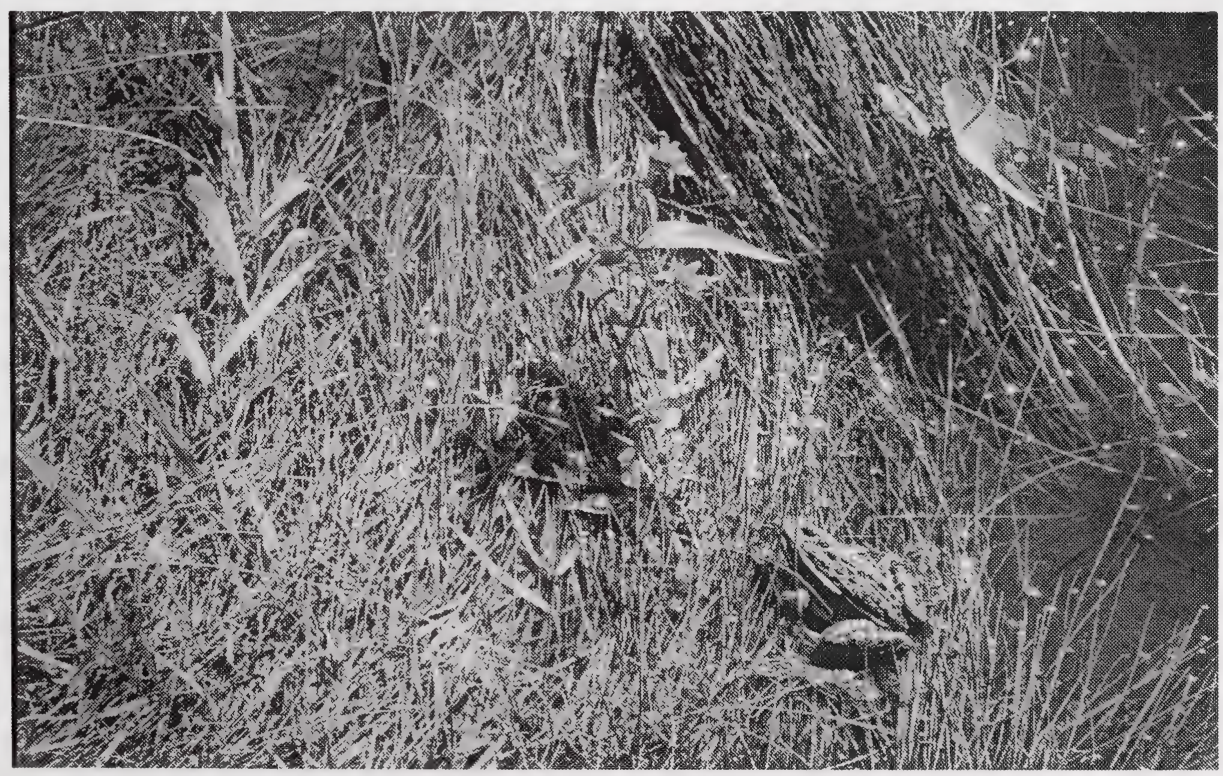

Photo 6. Northern leopard frog observed along the Galt Canal, Aug.26/03 
APPENDIX C - Numbers and locations of frogs observed throughout the 2003 field season, between July 15 and October 24

\begin{tabular}{|c|c|c|c|}
\hline Date & $\begin{array}{l}\text { \# Frogs } \\
\text { Observed }\end{array}$ & Location & $\begin{array}{c}\text { \# Search Hrs. } \\
\text { (Man hrs.) }\end{array}$ \\
\hline 15-Jul & 6 & Dudley's Pond & 5 \\
\hline 22-Jul & 24 & Dudley's Pond & 4 \\
\hline 28-Jul & 197 & Dudley's Pond & 4 \\
\hline 31-Jul & 108 & Dudley's Pond & 5 \\
\hline 4-Aug & 93 & Dudley's Pond & 4 \\
\hline 7-Aug & 106 & $\begin{array}{l}25 \text { along W side of Pothole Creek, } 81 \text { at Dudley's } \\
\text { Pond }\end{array}$ & 8 \\
\hline 12-Aug & 42 & 39 in Dudley's Pond, 3 in surrounding habitat & 4 \\
\hline 26-Aug & 4 & $\begin{array}{l}3 \text { on } E \text { side of canal, } 1 \text { just } E \text { of northern tip of pond } \\
\text { among vegetation }\end{array}$ & 4.5 \\
\hline 29-Aug & 2 & 1 on $E$ side of canal, $1 \mathrm{~d} / \mathrm{s}$ on $\mathrm{E}$ side of Pothole Creek & 3.5 \\
\hline 3-Sep & 10 & W side of Dudley's Pond among veg. on the shoreline & 4.5 \\
\hline 5-Sep & 12 & $\begin{array}{l}5 \text { along E side of canal, } 7 \text { near spillgate along } \\
\text { Pothole Creek }\end{array}$ & 4.5 \\
\hline 12-Sep & 10 & $\begin{array}{l}5 \text { on E side of Dudley's Pond, } 2 \text { by spillgate along } \\
\text { Pothole Creek, } 3 \text { west of spillgate on SW side of } \\
\text { Pothole Creek }\end{array}$ & 4 \\
\hline 19-Sep & 17 & Dudley's Pond & 4 \\
\hline 26-Sep & 2 & Along SW side of Pothole Creek (W of spillgate) & 4.25 \\
\hline 2-Oct & 5 & $\begin{array}{l}4 \text { on E side of canal, } 1 \text { along SW side of Pothole } \\
\text { Creek just downstream of golf club (furthest upstream } \\
\text { dispersal) }\end{array}$ & 4 \\
\hline 6-Oct & 6 & NW side of Pothole Creek (W of spillgate) & 4.25 \\
\hline 17-Oct & 8 & $\begin{array}{l}1 \text { near Pothole Creek rearing site, } 1 \text { on NW side } \\
\text { of Pothole Creek (W of spillgate), } 5 \text { on SW side } \\
\text { of creek (W of spillgate) }\end{array}$ & 4.25 \\
\hline 24-Oct & 5 & $\begin{array}{l}\text { Along W side of Pothole Creek (E of spillgate), } \\
\text { across from S end of Dudley's Pond }\end{array}$ & 4.5 \\
\hline
\end{tabular}




NATIONAL LIBRARY OF CANADA

|| ||| ||| |||||||| ||||||||||||||||||||||||||||||||||||||||||

3 3286528648955 